\title{
高ライズラチスドームの地震層せん断力係数に関する研究 STUDY ON STORY-SHEAR COEFFICIENTS FOR HIGH-RISE LATTICED SPHERICAL DOMES
}

\author{
加藤史 郎*, 向 山 洋 一** \\ Shiro KATO and Yoichi MUKAIYAMA
}

\begin{abstract}
The present paper studies the vibrational characteristics of high-rise latticed spherical domes subjected to horizontal earthquake motions. First, the maximum responses of story-shear forces at various heights in the domes are calculated by elastic linear time-domain analysis adopting three accelerations of ELCENTRO-NS, TAFT-EW and MTYAGI-NS. Secondly, the story-shear forces are summarized as the story-shear coefficients in both the horizontal and vertical directions for the coefficients to be applied in equivalent static analysis for the earthquake forces. The coefficients are expressed by combination of first natural period $T_{1}$, response spectra $S_{A}\left(T_{1}\right)$ and some other required parameters, representing the dynamic properties of domes. Lastly, the validity of the proposed scheme for static analysis is discussed by comparing the static results with those obtained by time-domain response analysis.
\end{abstract}

\author{
Keywords : latticed dome, earthquake response analysis, story-shear coefficient, \\ acceleration response spectrum
}

ラチスドーム, 地䟴応答解析, 層せん断力係数, 加速度応答スペクトル

\section{1. 序}

ドーム状棈造物の耐震性に関する研究1) 12)の多く は，比較的偏平なドームを対象として，主に上下動を取 り扱っており，水平動を取り扱ったものは少ない。ドー 么の規模が増大するのに伴い，水平地震動も耐震設計に 大きな影䛚を与えることが予想され，特に，高ライズの ドームに関しては，水平地震動に対する検討は必須条件 となろう。その検討に当たっては，ドームの地震応答性 状を各側面にわたって詳細に分析することも必要となる が, ドームの設計手法の確立という面から考えれば，高 層建築で採用されている層せん断力係数 $\mathrm{C}_{\mathrm{i}}$ あるいはそ の分布係数 $\mathrm{A}_{\mathrm{i}}{ }^{13}$ が，ドームの形状によってどのような 値を取るかを検討することも必要となる。

筆者らはこのような立場から，前報14)において，半開 角 $\phi=90^{\circ}$ の単層ラチスドームの地震応答性状について検 討を行い, 地震加速度応答スペクトルより層せん断力係 数が推定できること，また，それを用いた静的弾塑性解
析からドームの耐力が推定できることを示している。 そこで，本研究では前報に引き続き，図－1 および表 - 1 に示すように $\phi$ が $60^{\circ} \sim 120^{\circ}$ の範囲の単層ラチスド 一ムを対象とし, 層せん断力係数に焦点を絞り検討を行 う。なお, 半開角が $\phi=60^{\circ}$ より小さいものに関しては, 上下動を含めた検討が必要となるので，今後の検討課題 とする。層せん断力係数の分析に当たっては，前報と同 様にドームの 1 次固有周期と地震加速度応答スペクト ル，今回はさらに，ドームの半開角 $\phi$ をパラメータとし た関数を用いる。また，水平地震動を受けるドームに対 して，従来ほとんど分析されていなかった鈶直方向の振 動に対する層せん断力係数に対しても検討を行う。

\section{2. 解析モテル}

\section{1 ドームの全体形状}

単層ラチスドームの形状は，図ー 1 に示す円形平面を
* 豊橋技術科学大学建設工学系 教授. 工博

* 豊橋技術科学大学建設工学系 大学院生・工修 (巴コーポレーション技術開発部)
Prof., Dept. of Architecture and Civil Eng., Toyohashi Univ. of Technology, Dr. Eng.

Graduate student, Dept. of Architecture and Civil Eng., Toyohashi Univ. of Technology, M: Eng. (Engineering Development Division Tomoe Corporation) 
有する球形である。ドームのスパン L（ドームの最大

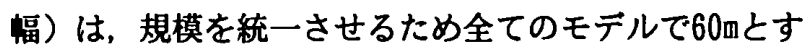
る。ドームのライズHは，半開角 $\phi$ をパラメータとし，

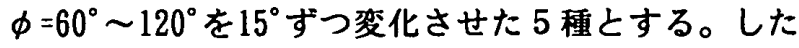
がって, ドームの曲率半径Rは $\phi=60^{\circ}$ で最大の $34.64 m$ と なり， $\phi \geqq 90^{\circ}$ の場合は 30.00 只なる。ドームの形状例 として, $\phi=60^{\circ}, 90^{\circ}, 120^{\circ}$ のドームを図ー 1 に示す。各 ドームの半開角 $\phi に$ 対する形状諸元を表 - 1 に示す。表 中の 另はドームを構成する部材長さの平均値であり， 自a就よび 囱inは，それぞれ部材長さの最大值と最小值 である。また, ドームは全体が 1 種類の部材で構成され ているものとする。

各層の $\mathrm{Z}$ 座標は，緯度方向に角度で等分することに よって定められ， $\phi=60^{\circ}, 75^{\circ}, 90^{\circ}$ では 12 等分， $\phi$ $=105^{\circ}, 120^{\circ}$ はそれぞれ14,16等分されている。各首にお ける節点の X, Y 座標は, 平面内で経度の方向に角度で 8〜32等分することによって定められている。

なお，効率的にパラメトリックな数值解析を実行する ため，力学的性状に関してX軸についての対称性を仮定 し，図- 1 に示す $1 / 2$ 領域を解析する。

\section{2 部材モテル}

単層ラチスドームを構成する部材は，図ー 2 に示すよ うにばねと梁から成るものとし，ねじり用性は無視し得 るものとする。解析に用いる部材断面は鎆管を仮定し, その部材諸元を表 -2 に示す。表中の $\lambda_{0}$ は各ドームの 平均部材長さ $l_{0} に$ 対する部材細長此である。部材端の回 転ばね定数 $\mathrm{K}_{\mathrm{B}}$ (ただし， $\mathrm{K}_{\mathrm{By}}=\mathrm{K}_{\mathrm{B} Z}=\mathrm{K}_{\mathrm{B}}$ とする）は剛接

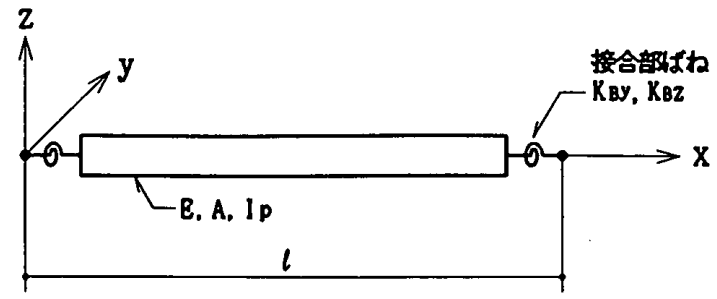

$A$ : 町面积, I : 盽面2次モーメント E:ヤング $\left(=2100 \mathrm{tf} / \mathrm{cm}^{2}\right)$

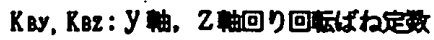
$\ell:$ 觔材長さ

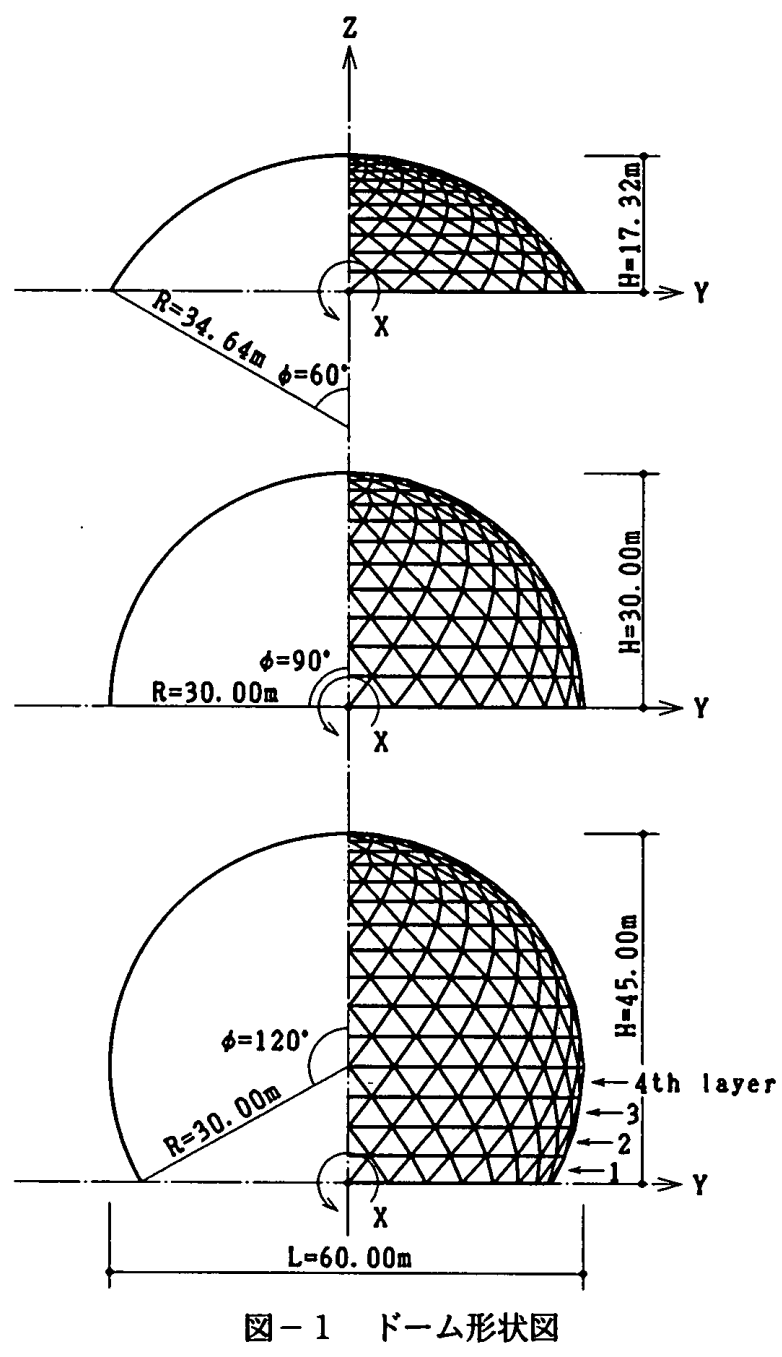

表ー 1 ドーム形状諸元

\begin{tabular}{|c|c|c|c|c|c|c|}
\hline & $\begin{array}{c}\mathrm{L} \\
(\mathrm{m})\end{array}$ & $\begin{array}{c}\mathrm{H} \\
(\mathrm{m})\end{array}$ & $\mathrm{H} / \mathrm{L}$ & $\begin{array}{c}l_{0} \\
(\mathrm{~m})\end{array}$ & $\begin{array}{c}l_{\max } \\
(\mathrm{m})\end{array}$ & $\begin{array}{c}l_{\min } \\
(\mathrm{m})\end{array}$ \\
\hline$\phi=60^{\circ}$ & 60.00 & 17.32 & 0.29 & 3.80 & 5.88 & 2.31 \\
\hline$\phi=75^{\circ}$ & 60.00 & 23.02 & 0.38 & 4.13 & 5.88 & 2.57 \\
\hline$\phi=90^{\circ}$ & 60.00 & 30.00 & 0.50 & 4.61 & 5.88 & 2.94 \\
\hline$\phi=105^{\circ}$ & 60.00 & 37.76 & 0.63 & 4.70 & 5.88 & 2.94 \\
\hline$\phi=120^{\circ}$ & 60.00 & 45.00 & 0.75 & 4.74 & 5.88 & 2.94 \\
\hline
\end{tabular}

図ー2 部材モテル

表 -2 部材諸元

\begin{tabular}{|c|c|c|c|c|c|c|c|}
\hline \multirow{2}{*}{ 部材サイス } & \multirow{2}{*}{$\mathrm{A}\left(\mathrm{cm}^{2}\right)$} & \multirow{2}{*}{$\operatorname{Ip}\left(\mathrm{cm}^{4}\right)$} & \multicolumn{5}{|c|}{$\lambda_{0}$} \\
\hline & & & $\phi=60^{\circ}$ & $\phi=75^{\circ}$ & $\phi=90^{\circ}$ & $\phi=105^{\circ}$ & $\phi=120^{\circ}$ \\
\hline P-114. 3×3. 5 & 12.18 & 187.0 & 97 & 105 & 118 & 120 & 121 \\
\hline P-165. 2x4.5 & 22.72 & 734.0 & 67 & 73 & 81 & 83 & 83 \\
\hline P-216. 3x5. 8 & 38.36 & 2130.0 & 51 & 55 & 62 & 63 & 64 \\
\hline
\end{tabular}


合を仮定し, 式 (1)で示す無次元回転ばね定数 $\kappa$ の値で 1000 とする。

$$
\kappa=K_{B y} \cdot\left(l_{0} / E \text { I } p\right)=K_{B Z} \cdot\left(l_{0} / E \text { I } p\right)
$$

\section{3 ドームの自重および境界条件}

ドームの自重Wは単位表面積当たり $100,200,300 \mathrm{kgf} / \mathrm{m}^{2}$ の 3 種とし, 各節点の荷重負担面積より計算される重量 から集中質量として与える。

境界条件は，ドームの底部各節点を固定支持とする。

\section{4 入力地震加速度波形}

入力地震加速度は, ELCENTRO-NS(1940), TAFT-EW(1952) とMIYAGI (TOUHOKU UNIV. )-NSの 3 波とし，入力加速度 の最大值 Amaxを100gal とする。入力波に対する加速度 応答スペクトル $S_{A}$ を図ー 3 に示す。図中, 塗り潰した 部分は, 本解析で用いたドームの 1 次固有周期 $\mathrm{T}_{1}$ の範 囲である。

以上, 4 つのパラメータ(ドームの半開角 $\phi$, 部材サイ ズ，自重w，入力地震波)の組合せによる135( $=5 \times 3 \times 3 \times 3)$ ケースに対して解析を行う。

\section{3. 解析方法}

本研究では，ドームの層せん断力係数 $\mathrm{C}_{\mathrm{i}}$ 分布を求め るため, 線形地震応答解析を行う。応答解析法は, ニューマークの $\beta$ 法とし， $\beta$ の值は $1 / 4$ （平均加速度 法）とする。减衰は剛性比例型とし，その定数の值は 1 次固有周期に対して $2 \%$ とする。入力波の継続時間は, ELCENTRO, TAFTで10秒，MIYAGIで20秒とする。また，時 間刻み $\Delta$ tは, ELCENTRO, TAFTで0.01秒とし, MIYAGIで は計算時間の短縮のため0.02秒とする。

本解析において，地震荷重は図一 4 に示すようにX方 向に加振するものとし, 層せん断力係数は $\mathrm{X}$ 方向の水平 成分亡 $Z$ 方向の鉛直成分に分けて検討を行う。先ず水平 成分の層せん断力係数 $\mathrm{C}_{\mathrm{Hi}}$ は, $\mathrm{X}$ 方向の加速度から求め るものとする。すなわち， $\mathrm{i}$ 首の層せん断力係数 $\mathrm{C}_{\mathrm{Hi}}$ は， $\mathrm{i}$ 層より上部の質点の加速度に質量を乗し，それら を合計したものを $\mathrm{i}$ 首より上部の重量で除した值とす る。また，その値は時刻歴応答での最大值とする。次に 銛直成分の層せん断力係数 $\mathrm{C}_{\mathrm{V}_{\mathrm{i}}}$ は， $Z$ 方向の加速度から 求めるものとするが，X方向と同様に単に加速度と質量 を乗じ合計した場合，Y 軸に対称な節点同士で相殺され るため， $\mathrm{X}<0$ と X $>0$ の領域に分割し，別々に求める。

\section{4. 解析結果}

4.1 ドームの 1 次固有周期 $\mathrm{T}_{1}$

自重 $\mathrm{w}=100 \mathrm{kgf} / \mathrm{m}^{2}$ に対する各ドームの 1 次固有周期 $T_{1}$ の值を表 -3 に示す。 $\mathrm{w}=200,300 \mathrm{kgf} / \mathrm{m}^{2}$ に対する $\mathrm{T}_{1}$
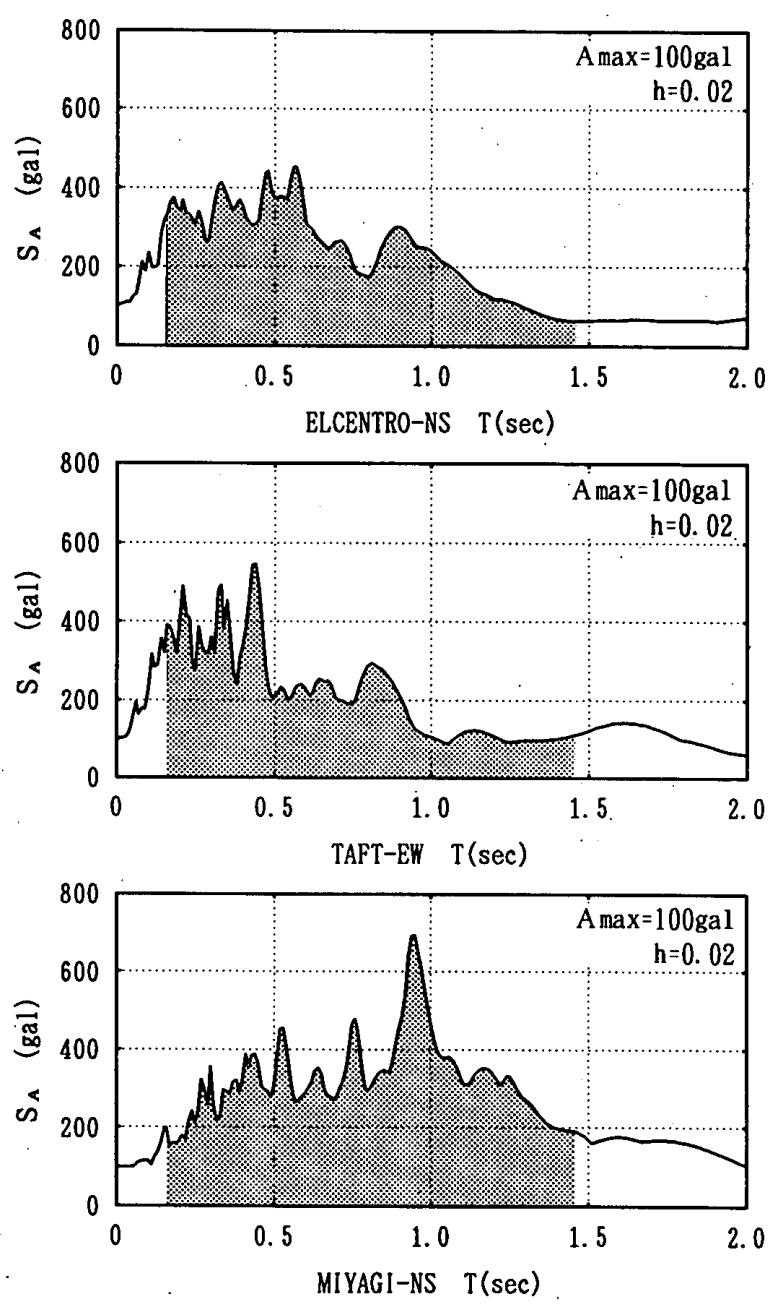

図ー3 加速度応答スペクトル

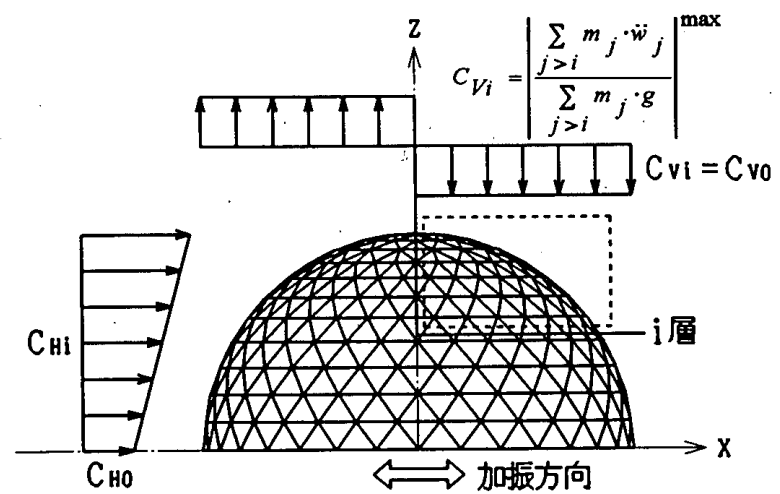

図－4 ドームに作用する静的荷重

表 -3 ドームの 1 次固有周期 $\mathrm{T}_{1}(\mathrm{sec})$

$\mathrm{w}=100 \mathrm{kgf} / \mathrm{m}^{2}$

\begin{tabular}{|c|c|c|c|c|c|}
\hline 部材サイス & $\phi=60^{\circ}$ & $\phi=75^{\circ}$ & $\phi=90^{\circ}$ & $\phi=105^{\circ}$ & $\phi=120^{\circ}$ \\
\hline P-114. 3x3.5 & 0.280 & 0.329 & 0.434 & 0.591 & 0.845 \\
\hline P-165.2x4.5 & 0.205 & 0.240 & 0.317 & 0.432 & 0.617 \\
\hline P-216.3x5.8 & 0.157 & 0.184 & 0.243 & 0.331 & 0.473 \\
\hline
\end{tabular}


は， $\mathrm{w}=100 \mathrm{kgf} / \mathrm{m}^{2}$ に対する値をそれぞれ $\sqrt{2}$ しくは $\sqrt{3}$ 倍した值である。したがって, 本解析で用いるドームの $\mathrm{T}_{1}$ の範囲は, 0.157〜1.464secである。

各 1 次固有周期 $\mathrm{T}_{1}$ に対する固有モードは, ほとんど のモデルで水平方向の振動モードを示したが, ドームの 半開角 $\phi=60^{\circ}$, 部材サイズP-114のモテルのみ上下方向 の振動モードを示した。したがって， $\phi=60^{\circ}, \mathrm{P}-114$ のモ テルに対しては，各モードにおける水平方向（X方向） の刺激係数を求めその値の最も大きい 8 次の固有周期を $\mathrm{T}_{1}$ とする。その固有周期と刺激係数の関係を表 -4 に 示す。ドームの半開角 $\phi=60^{\circ}, 90^{\circ}, 120^{\circ}$ で部材サイズP114のモテルに対する 1 次の固有モードを, 図ー 5 に示 す。このモード図より， $\phi=90^{\circ}$ のドームは $Z$ 方向の変形 をほとんど示していないのに対して， $\phi=60^{\circ}, 120^{\circ}$ の ドームはX方向の変形亡同時に $Z$ 方向にも装形している のが分かる。また，図中に矢印で示すように， $\phi=60^{\circ}$ の ドームは, X方向が正の変形に対して Z方向は右上がり に変形しているのに対して， $\phi=120^{\circ}$ のドームは，Z方 向が右下がりに変形している。

\section{2 加速度応答值分布}

各質点に作用する加速度応答值分布を図一 6 に示す。 これは， $\phi=60^{\circ}, 90^{\circ}, 120^{\circ}$, 部材サイズP-114, 自重 $\mathrm{w}$ $=100 \mathrm{kgf} / \mathrm{m}^{2}$ のドームに対して, ELCENTRO波を入力した場 合の応答値であり, 水平方向 ( $X$ 方向) 之鉛直方向 ( $Z$ 方向）を分けて示している。Y方向の応答に関しては, きわめて小さいので省略している。また，この分布は， 水平方向および鈶直方向のベースシアー係数 $\mathrm{C}_{\mathrm{H} 0}, \mathrm{C}_{\mathrm{V}_{0}}$ の值が最大となった時刻に対して示したものであり, 両 者の時刻は一致していない。

この図より, ドームは水平地震動のみ受けているにも かかわらず，鈶直方向にも振動し力が加わっていること が分かる。また，支持点からある程度離れた節点に対し て, X方向の加速度は, 高さと円周方向にほほ均一な分 布を示しているのに対して，Z方向の加速度は, 各層に おいてX座標の絶対値の大きさにほぼ比例し大きくなっ ており, 当然のことであるがY軸に対して逆対称となっ ている。これは, 加速度応答が図ー 5 に示す 1 次の固有 モードと密接に対応しているためと考えられる。さら に，ドームの半開角 $\phi$ との関係を見た場合， $\phi$ $=60^{\circ}, 120^{\circ}$ と比較し, $\phi=90^{\circ}$ では $Z$ 方向の加速度の值は 小さいことが分かる。これも固有モードと対応している ためであるが，最下屇の立上がり角度の影響が最も大き いと考えられる。すなわち，水平地震荷重を受け層間変 形が最も大きくなる最下層に対して，その立上がり角度 が $90^{\circ}$ に近いほど $Z$ 方向の変形が小さくなるため, 加速 度応答も小さくなると考えられる。

図ー7に，各ドーム頂部より 8 層目の節点（図一6に 示す点 $\mathrm{a}, \mathrm{b}, \mathrm{c}$ ）の絶対加速度時刻歴応答を示す。こ
の図より， $\phi=60^{\circ}$ のドームの場合，X方向に正の力が作 用した時 $Z$ 方向も正の力が作用しているのに対して， $\phi$ $=90^{\circ}, 120^{\circ}$ の場合は逆の応答を示しているのが分かる。 すなわち，静的解析において鉛直方向の力を考虑する場 合は, 図一 8 に示すように $\phi<90^{\circ}$ と $\phi \geqq 90^{\circ}$ で荷重を逆 方向に加える必要がある。

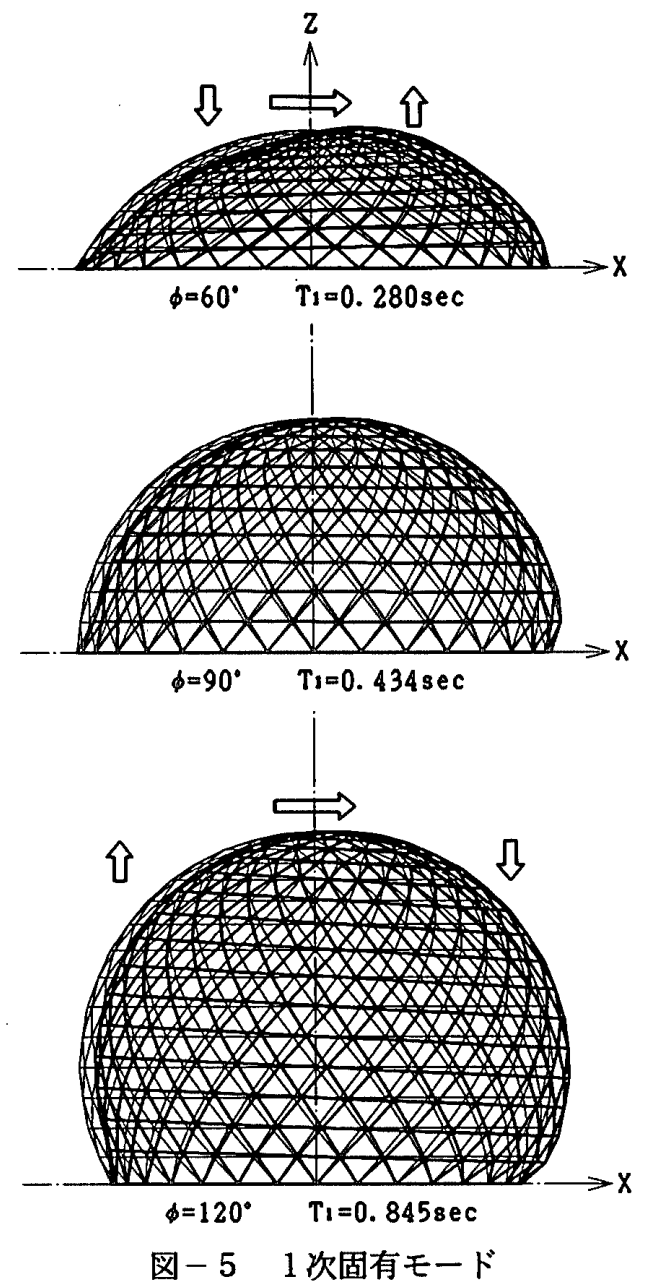

表-4 固有周期と刺激係数（ $\left.\phi=60^{\circ}, \mathrm{P}-114\right)$

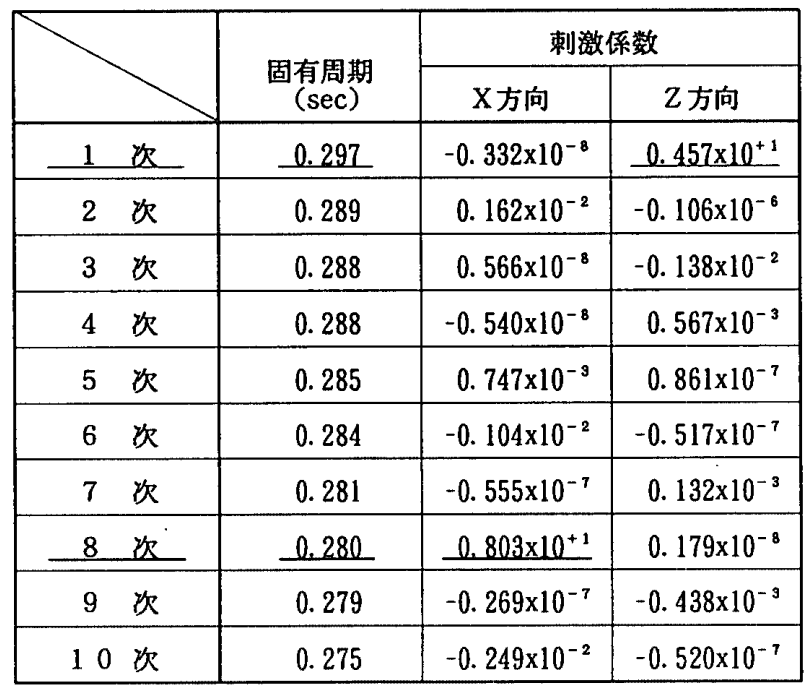




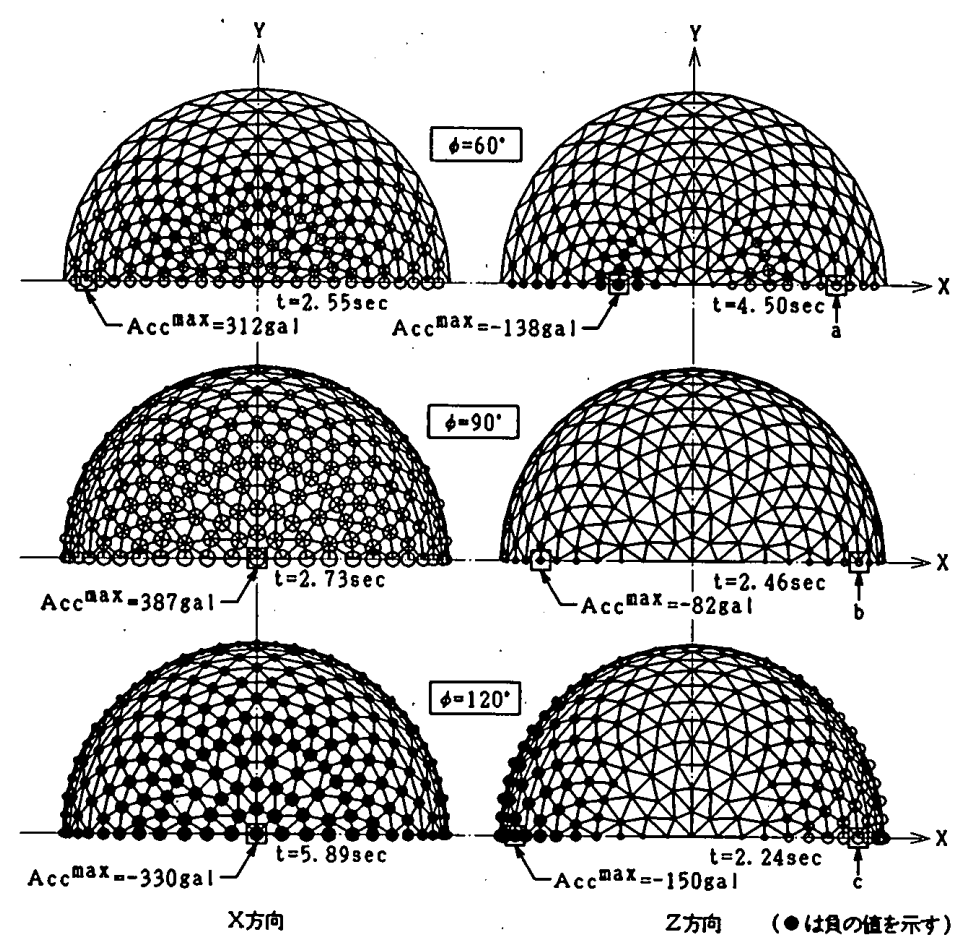

図 - 6 加速度応答值分布
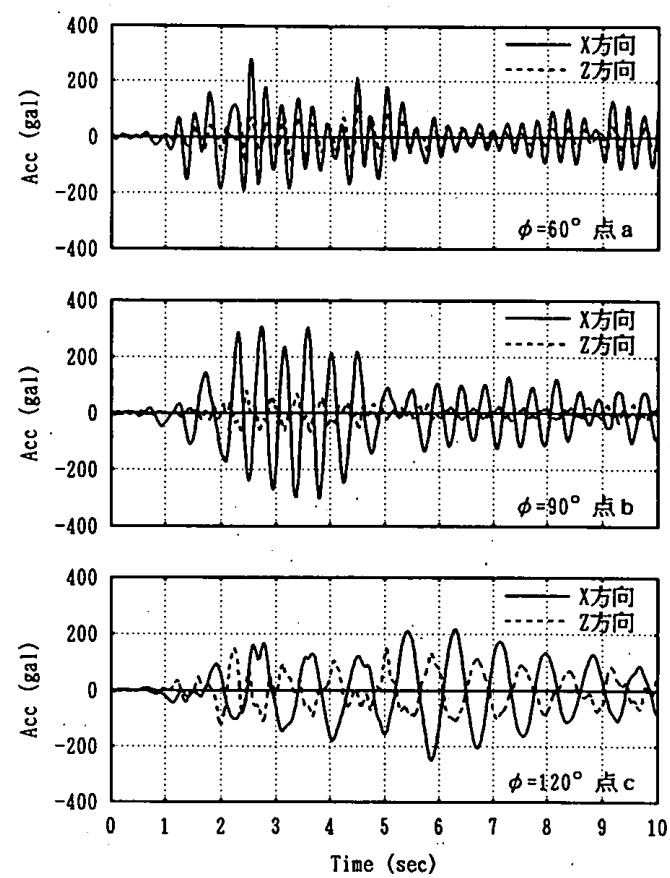

図 -7 時刻歴加速度応答

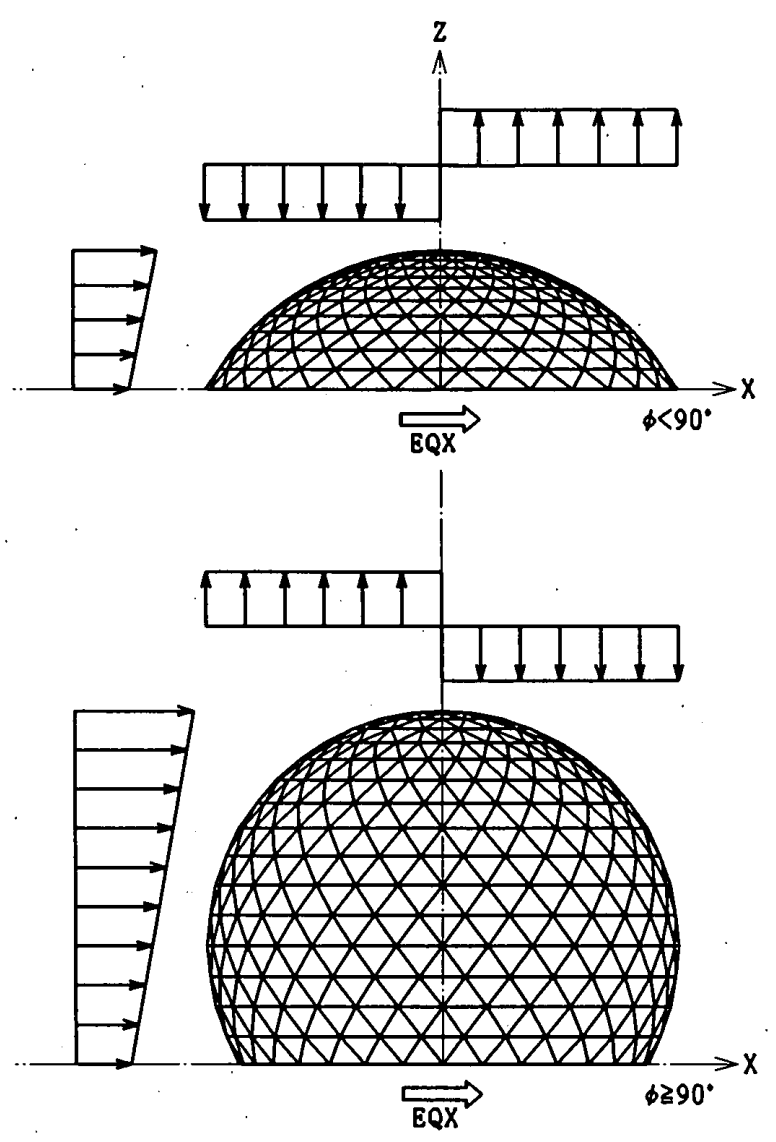

図 - 8 鈶直方向に作用する荷重方向

\section{3 層せん断力係数分布}

水平および鉛直方向の層せん断力係数 $\mathrm{C}_{\mathrm{Hi}}, \mathrm{C}_{\mathrm{Vi}}$ 分布 の例を図 -9 に示す。これは，ドームの半開角 $\phi$ $=60^{\circ}, 90^{\circ}, 120^{\circ}$ のモデル対して示したものであり，横 軸はべースシアー係数 $\mathrm{C}_{\mathrm{H} 0}, \mathrm{C}_{\mathrm{V} \mathrm{O}}$ で，緃軸はドームのラ イズHで無次元化されている。この図より，水平方向の 層せん断力係数分布 $\mathrm{C}_{\mathrm{Hi}}$ は， $\phi$ が大きくなるほど $\mathrm{C}_{\mathrm{H} 0}$ に 対するドーム頂部の応答が大きくなっていることが分か る。それに反して, 鉛直方向の $\mathrm{C}_{\mathrm{Vi}}$ は $\phi$ が小さいほど頂 部の応答が大きくなる傾向にある。また, $\mathrm{C}_{\mathrm{Hi}}$ は高さ方 向に対してほぼ線形的に大きくなっている。

筆者らは, 前報14)において $\phi=90^{\circ}$ のドームの $C_{\mathrm{i}}$ 分布 の推定法について検討している。それは，ドームが 1 次 固有周期で振動しているものと仮定し，ベースシア一係 数 $\mathrm{C}_{\mathrm{H} O}$ を, 地震波の応答スペクトルを用いて推定し， $\mathrm{C}_{\mathrm{Hi}}$ 分布は, 高さ方向に線形的に近似させようとするもので ある。そこで，本研究では，さらにドームの半開角 $\phi を$ パラメータとしたドームの層せん断力係数の推定法につ いて検討を行う。

先ず前報と同様に, ベースシアー係数 $\mathrm{C}_{\mathrm{H} 0}$ お゙よび層せ ん断力係数 $\mathrm{C}_{\mathrm{Hi}}$ を，式(2)，(3)を用いて表現する。

$$
\begin{aligned}
& \mathrm{C}_{\mathrm{H} 0}=\alpha(\phi) \cdot \mathrm{Sa}\left(\mathrm{T}_{1}\right) \\
& \mathrm{C}_{\mathrm{Hi}}=\mathrm{C}_{\mathrm{H} 0} \cdot(1+\beta(\phi) \cdot \mathrm{h} / \mathrm{H})
\end{aligned}
$$


ここで, $\mathrm{Sa}\left(\mathrm{T}_{1}\right):$ 正規化加速度応答スペクトル

$$
\left(=\mathrm{S}_{\mathrm{A}}\left(\mathrm{T}_{1}\right) / \mathrm{g}\right)
$$

$\mathrm{T}_{1}:$ ドームの 1 次固有周期 $(\mathrm{sec})$

$\mathrm{g}:$ 重力加速度 $\left(=980 \mathrm{~cm} / \mathrm{sec}^{2}\right)$

$\mathrm{H}:$ ドームの高さ $(\mathrm{m})$

$\mathrm{h}: \mathrm{i}$ 層の高さ $(\mathrm{m})$

これらの式では，係数 $\alpha$ および $\beta$ の值を定めれば，ドー ムの 1 次固有周期と加速度応答スペクトル $S_{A}\left(T_{1}\right) に よ$ り $\mathrm{C}_{\mathrm{Hi}}$ が推定できる。本解析によって求められた $\alpha$ およ び $\beta$ 值をそれぞれ図-10，11に示す。図中，○は 解析値を示し, 実線と点線はそれぞれ解析値の平均値亡 標準偏差 $\sigma$ を示している。
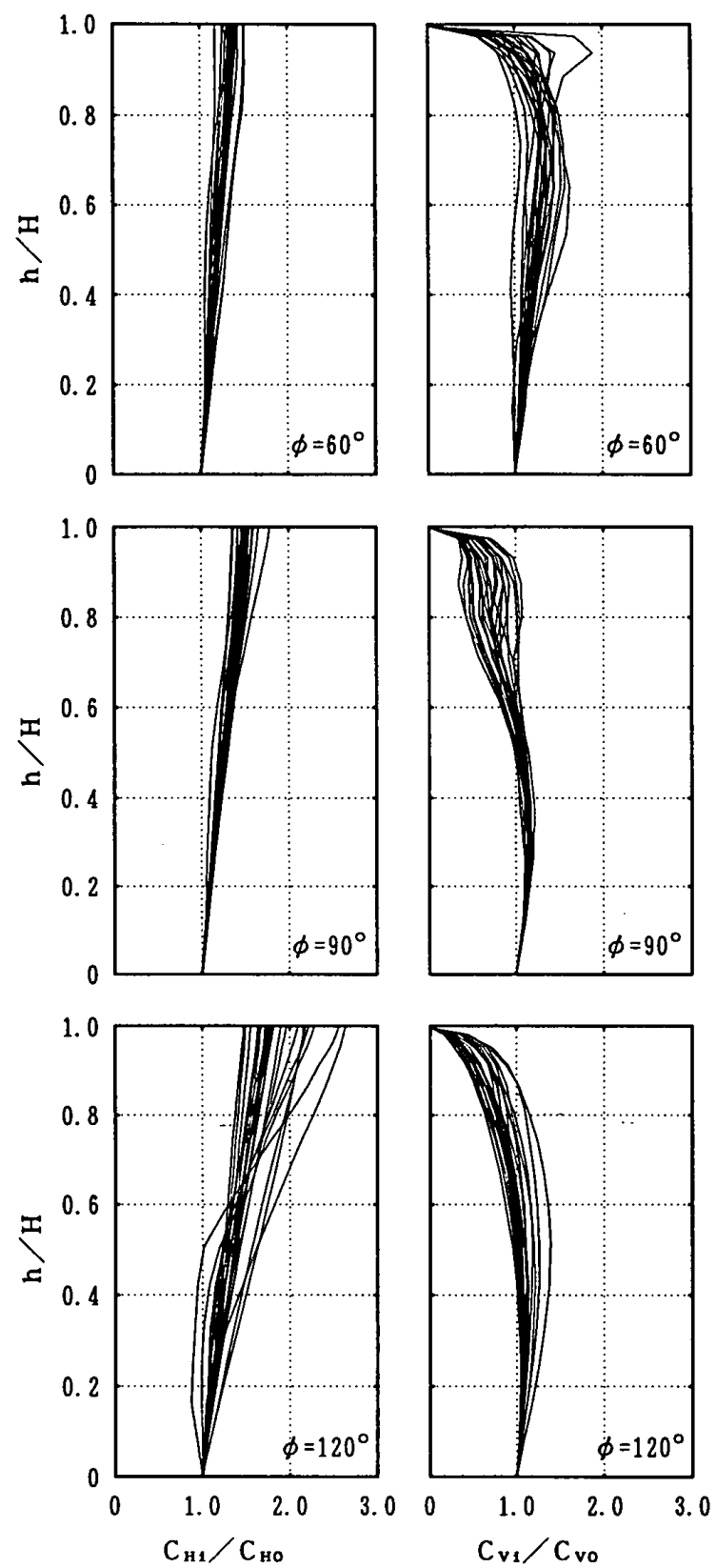

図-9 $\mathrm{C}_{\mathrm{Hi}}$ および $\mathrm{C}_{\mathrm{Vi}}$ 分布

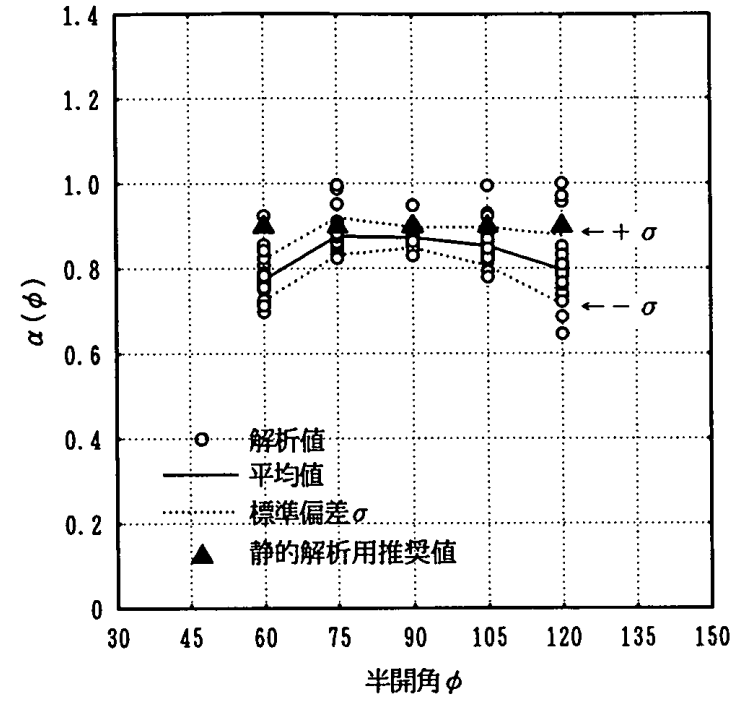

図-1 $0 \quad \phi-\alpha$ 関係

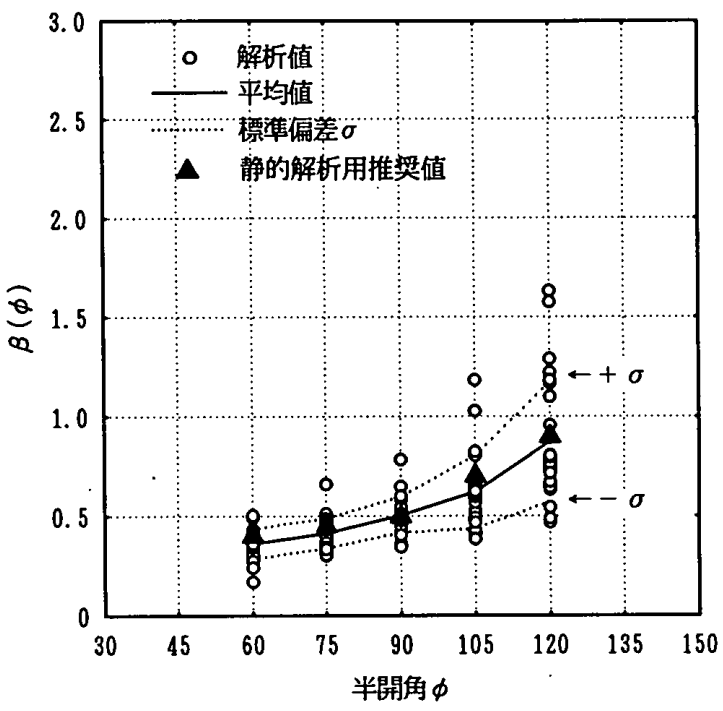

図-11 $\phi-\beta$ 関係

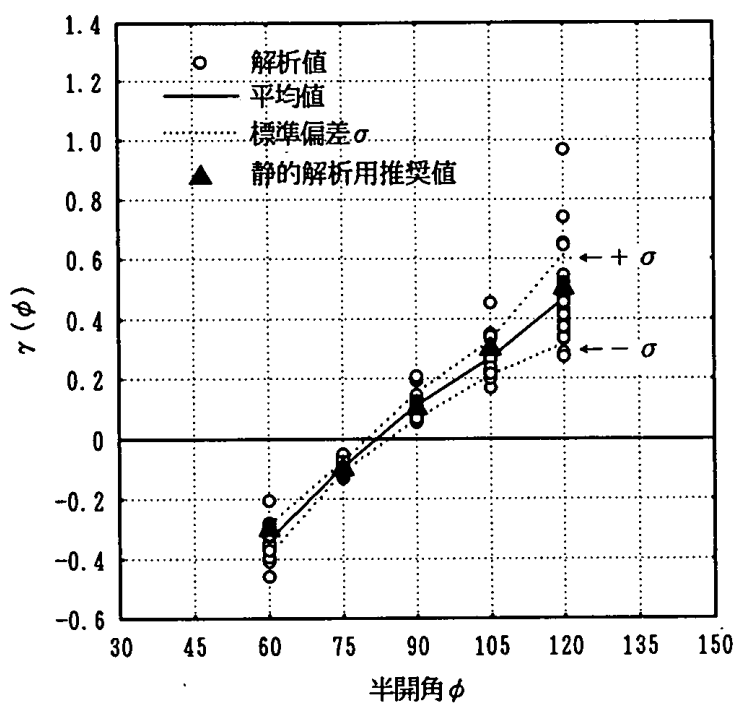

図-12 $\phi-\gamma$ 関係 
図ー 10 より, $\alpha$ の值はほぽ0.6〜1.0の間に分布して おり, 平均值は $\phi=75^{\circ} \sim 90^{\circ}$ を頂点とし, そこから離れ るほど小さくなる傾向にある。さらに， $\phi=90^{\circ}$ でばらつ きが一番小さく， $\phi=90^{\circ}$ から離れるほどばらつきが大き くなっている。すなわち， $\phi=90^{\circ}$ 附近のドームが最も1 質点系に近い応答を示していると考えられる。また，図 -11 より， $\beta$ の平均値は $\phi$ が大きくなるにしたがい きくなっており，ばらつきも大きくなっている。

次に，鉛直方向の層せん断力係数 $\mathrm{C}_{\mathrm{Vi}}$ を式(4)，(5)を 用いて表現する。

$$
\begin{aligned}
& \mathrm{C}_{\mathrm{V} 0}=\gamma(\phi) \cdot \mathrm{C}_{\mathrm{H} 0} \\
& \mathrm{C}_{\mathrm{Vi}}=\mathrm{C}_{\mathrm{V} 0}
\end{aligned}
$$

本解析によって得られる $\gamma$ の値を図ー12に示す。鈶直 方向に作用するせん断力に関しては，図－8に示すよう に $\phi<90^{\circ}$ と $\phi \geqq 90^{\circ}$ で方向が逆になるため，X軸に対し て正の方向にせん断力が作用したとき，Y軸に対して右 回りのモーメントが発生する場合の $\gamma$ を正とする。この $\gamma$ の值より, $\phi=75^{\circ}$ と $\phi=90^{\circ}$ の間で鉛直荷重の方向が逆 転しており，この付近では鉛直方向の応答が小さいこと が分かる。しかし， $\phi=60^{\circ}, 120^{\circ}$ に対する $\gamma$ の值は大き く，静的解析に対する銛直方向の荷重の影響は無視でき ないと考えられる。

高さ方向の $\mathrm{C}_{\mathrm{V}_{\mathrm{i}}}$ 分布は, 図一 9 に示すように $\mathrm{C}_{\mathrm{V}_{0}}$ に対 して多少凸凹しているが，水平地震荷重を受け最も大き なせん断力を受ける最下層に注目した場合，その分布の 影響は小さいため一律 $\mathrm{C}_{V 0}$ の値を用いるものとする。

\section{5. 動的およひ静的解析による断面力の比較}

5.1 静的解析用定数 $\alpha, \beta, \gamma$ を用いた解析

以上の解析結果より, ドームの半開角 $\phi$ をパラメータ とした静的解析用定数を以下のように仮定する。先ず $\alpha$ に関しては，標準偏差 $\sigma$ を参考にし，一律 $\alpha=0.9$ とす る。次に， $\beta$ および $\gamma に$ 関しては，之の平均値を参考に し， $\beta$ は 2 直線， $\gamma$ は直線によって近似する。その各值 を表一 5 に示す。また，図－10，11，12には，そ の值をムマークで示している。ここで定めた $\alpha, \beta, \gamma$ と 地震加速度応答スペクトル $\mathrm{S}_{\mathrm{A}}\left(\mathrm{T}_{1}\right)$ を用いてそれそれ $\mathrm{C}_{\mathrm{Hi}}$ $\mathrm{C}_{\mathrm{Vi}}$ を計算し，図一 4 に示す静的荷重により線形解析を 行う。Z方向の静的荷重の作成にあたって, 図一 6 の加 速度分布に示されるように, 各層内で変化させるのが望 ましいが，荷重の入力が繁雑となり実用的ではないの で，Z方向荷重は各層で平均化して与える。

\section{2 断面力の比較}

動的および静的解析による断面力の比較を行う際に, すへての部材で比較するのは大変困難となるので，上層
表 -5 静的解析用定数 $\alpha, \beta, \gamma$

\begin{tabular}{|c|r|r|r|r|r|}
\hline & $\phi=60^{\circ}$ & $\phi=75^{\circ}$ & $\phi=90^{\circ}$ & $\phi=105^{\circ}$ & $\phi=120^{\circ}$ \\
\hline$\alpha$ & 0.90 & 0.90 & 0.90 & 0.90 & 0.90 \\
\hline$\beta$ & 0.40 & 0.45 & 0.50 & 0.70 & 0.90 \\
\hline$\gamma$ & -0.30 & -0.10 & 0.10 & 0.30 & 0.50 \\
\hline
\end{tabular}

と最下層そしてその中間の 3 層を選び出し，それぞれ最 も大きな軸力を受ける斜材に注目し検討する。ここで， 上層は半開角 $\phi$ にかかわらず頂部から 3 層目とし, 中層 は $\phi=60^{\circ} \sim 90^{\circ}$ は頂部から 7 層目， $\phi=105^{\circ}, 120^{\circ}$ はそれ ぞれ 8，9層目とする。なお，静的荷重は，鉛直方向の 層せん断力係数の影響を調へるため， $\mathrm{C}_{\mathrm{Hi}}$ のみ考虑した 場合と $\mathrm{C}_{\mathrm{Hi}}, \mathrm{C}_{\mathrm{Vi}}$ の両方を考慮した場合の 2 ケースの軸 力を計算する。 $\mathrm{C}_{\mathrm{Hi}}$ のみ考慮した場合の斜材の最大軸力 を $\mathrm{N}_{\mathrm{H}}$ 妾とし， $\mathrm{C}_{\mathrm{Hi}}, \mathrm{C}_{\mathrm{Vi}}$ の両方を考慮した場合の最大軸 力を $\mathrm{N}_{\mathrm{HV}}{ }^{\max }$ とする。また，動的解析より得られる最大軸 力を $\mathrm{N}_{\mathrm{D}} \max$ とする。 $\mathrm{N}_{\mathrm{D}}$ maxをそれぞれ $\mathrm{N}_{\mathrm{H}} \max$ と $\mathrm{N}_{\mathrm{HV}} \max$ 除した值 $\nu_{H}, \nu_{H V}$ ，図-13に示す。図中，実線と 点線はそれぞれ $\nu_{\mathrm{H}}, \nu_{\mathrm{HV}}$ の平均値と標準偏差 $\sigma$ を示し ている。図は上から上層，中層，下層の順に並んでお り，左側は水平荷重のみ考慮した場合，右側は水平と鉛 直の両方を考虑した場合である。

この図より， $\nu_{\mathrm{H}}$ よび $\nu_{\mathrm{HV}}$ の值は，上層ほど大きく なっており，またそのばらつきむ大きくなっている。次 に $\nu_{\mathrm{H}}$ と $\nu_{\mathrm{HV}}$ を比較すると, $\phi \geqq 90^{\circ}$ の場合は上層部の $\phi$ $=120^{\circ}$ 付近を除いて両者の差は小さいが, $\phi<90^{\circ}$ の場合

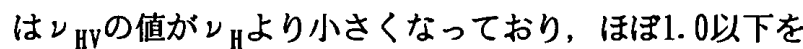
示している。これは，層せん断力係数として $\mathrm{C}_{\mathrm{Hi}}, \mathrm{C}_{\mathrm{V}_{\mathrm{i}}}$ の両方を考虑することの有効性を示したむのであり，水 平地震動に対する静的解析において，水平のみではなく 鉊直方向の荷重も考虑することにより，断面力がより安 全側に推定されている。ただし， $\phi \geqq 90^{\circ}$ の上層部で は， $\nu_{\mathrm{HV}}$ の値が 1.5 を越える場合もあり， $\phi \geqq 90^{\circ}$ の上首 部の軸力の推定にあたっては， $\nu_{\mathrm{HV}}$ の標準偏差 $\sigma$ を考虑 し多少割り增した值を用いる必要があると考えられる。

以上，動的および静的解析から得られる断面力の比較 により, 水平地震動を受けるドームの断面力は, ドーム の 1 次固有周期 $\mathrm{T}_{1}$, 地震加速度応答スペクトル $\mathrm{S}_{A}\left(\mathrm{~T}_{1}\right)$ および静的解析用定数 $\alpha, \beta, \gamma$ を用いて静的解析を行 うことにより，推定できると考えられる。

\section{6. 結語}

6.1 結論

本研究では，図ー 1 に示すような層状に組まれた高ラ イズの単首ラチスドームを対象とし，水平地震動に対す る層せん断力係数 $\mathrm{C}_{\mathrm{i}}$ 分布の検討を行った。限られた条 

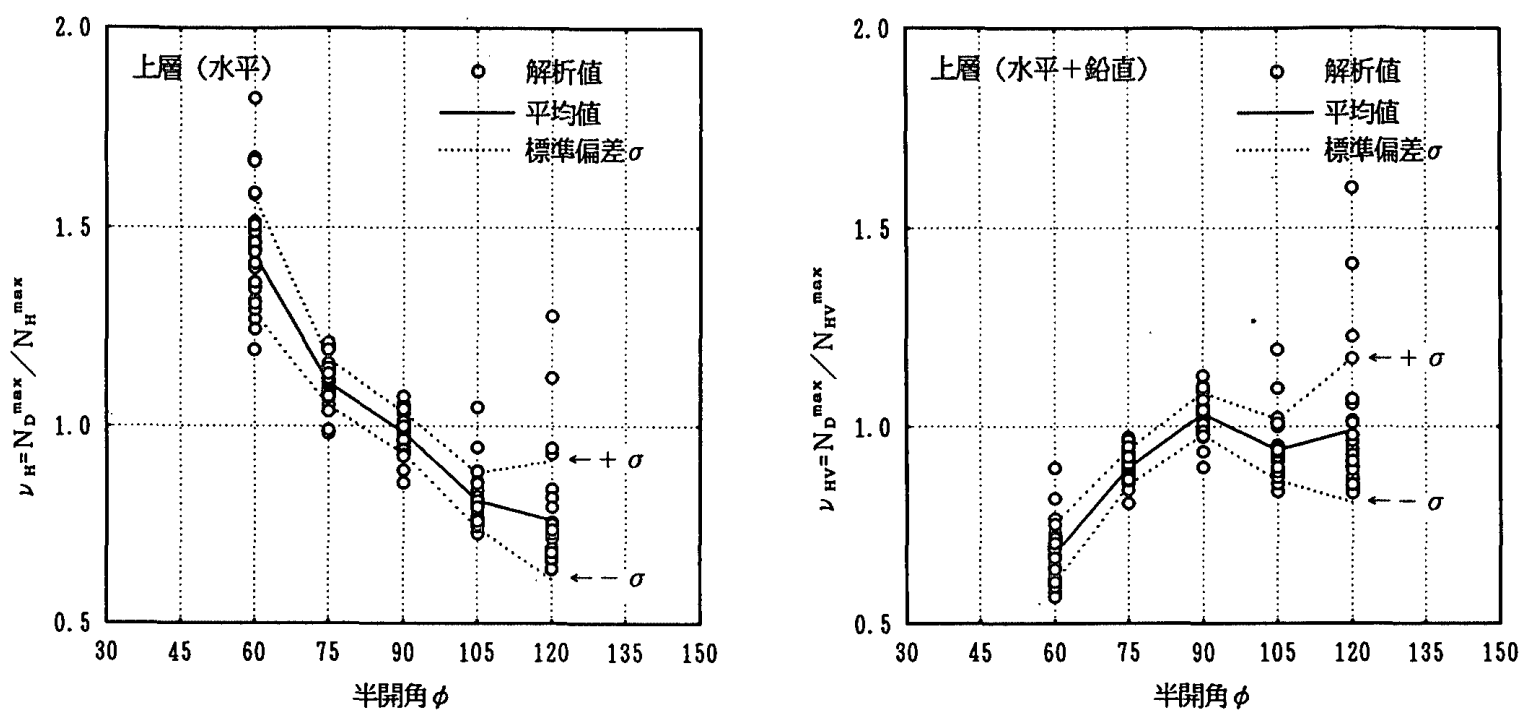

図-13（a）上層部 $\phi-\nu_{\mathrm{H}}, \nu_{\mathrm{HV}}$ 関係
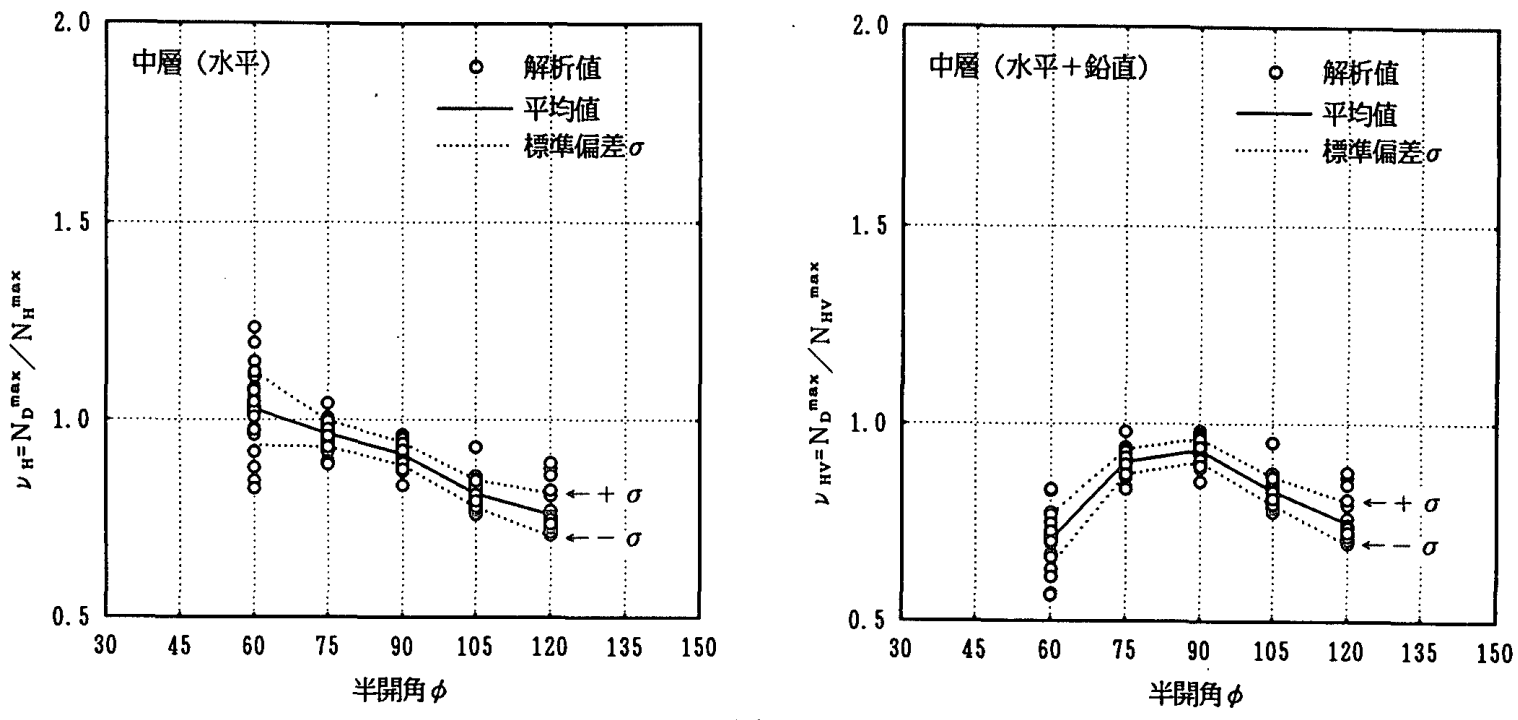

図-13（b） 中層部 $\phi-\nu_{\mathrm{H}}, \nu_{\mathrm{HV}}$ 関係
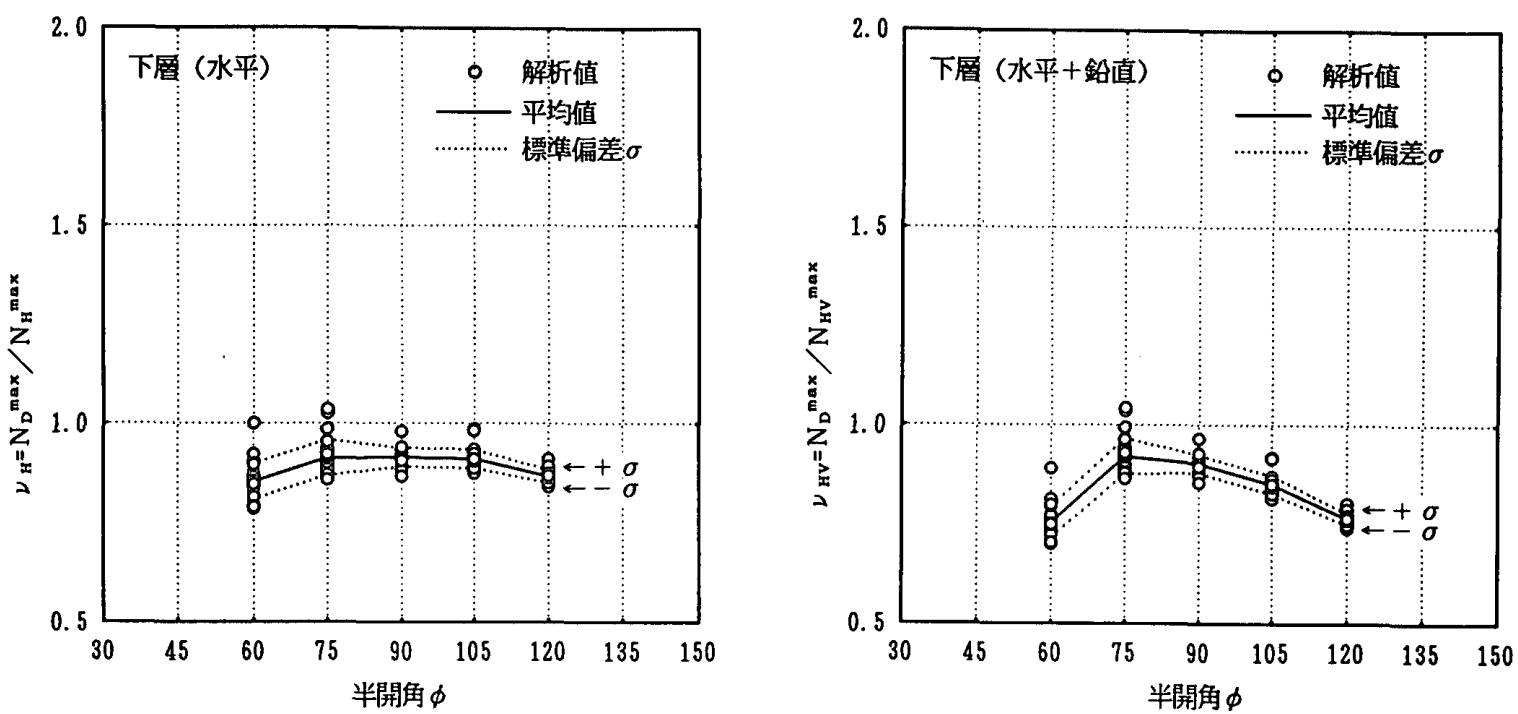

図-13（c） 下層部 $\phi-\nu_{\mathrm{H}}, \nu_{\mathrm{HV}}$ 関係 
件下ではあるが，得られたことを要約すると，

(1) 文献 3 ) で示されている結果と同様に, 水平地震 動を受けるドームに対しても局部的な鈶直力が発生して いることが認められた。また，その鉛直力は，ドームの 半開角 $\phi=90^{\circ}$ 附近で最屯小さくなり， $\phi$ が $90^{\circ}$ から離れ るほど大きくなることが分かった。

（2）水平方向の層せん断力係数 $\mathrm{C}_{\mathrm{Hi}}$ は, ドームの 1 次 固有周期之入力地震波の応答スペクトルによって整理さ

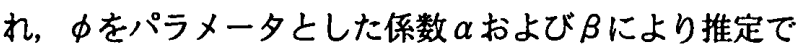
きることを示した。そして，鉊直方向の層せん断力係数 $\mathrm{C}_{\mathrm{Vi}}$ は, 水平方向のベースシアー係数 $\mathrm{C}_{\mathrm{H} 0}$ と係数 $\gamma$ に よって表せることを示した。

（3）表一 5 に示す静的解析用定数 $\alpha ， \beta ， \gamma$ を用いて 静的解析を行うことにより, 応答解析から得られる断面 力をほぼ安全側に推定できることを示した。

\section{2 今後の課題}

本研究では, まだ限られた場合の検討を行ったにとど まり，さらにこの考えを一般的なものにしていくために は, 今後の課題として,

（1）水平動と上下動を同時に受けた場合の挙動

（2）大スパン構造に対する地震波の位相の影響

（3）基碄，下部䊈造と上部構造を含めた応答性状

等を考慮し，地震波やモデルを変化させたパラメトリッ クな検討を進める必要がある。

\section{鄉群}

本研究を実施するにあたり，巴コーポレーション・松 下冨士雄博士，久保寺勲博士，植木隆司博士からは終始 有益な御助言を頂き，井手知佳子氏には図表作成に援助 を頂きました。ここに記して謝意を表します。

\section{考文蝴}

1）高島英幸，西園博美，加藤史郎：上下動を受ける矩形平面状 の屋根型偏平球款の応答性状，日本建築学会構造系論文報告 集, 第383号, pp. 58〜67, 1988. 1

2) 斎藤公男: スペース・ストラクチャーのデザイン, 季刊カラ 厶, Vol. 83, pp. $28 \sim 33,1982.1$

3）西村敏雄，新宮清志：上下動および水平動地震を受ける裙梁 付回転体シェルの動的応答に関する研究, 日本建筮学会構造 系論文報告集，第326号，pp. 47 59，1983.4

4 ）國枝治郎：上下動を受ける球形シェルの非線形応答解析, 日 本建築学会大会学術講演梗概集，pp. 1157 1158，1981.9

5 ) Haruo Kunieda: Solutions of Free Vibrations of Spherical Shells，日本建築学会構造系論文報告集，第325 号, pp. 57 66, 1983. 3

6) 田波徹行, 本間靖章, 半谷㭲彦 : 単層スペースフレームの振 動特性に関する研究（その 2 ．部材にバネを用いたモデルに

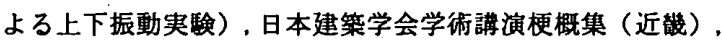
pp. $1309 \sim 1310,1987.10$
7）石川浩一郎 : スペースフレームの酎荷力に関する解析的研究. 豊橋技術科学大学博士学位論文, 1990

8 ）加藤史郎, 石川浩一郎, 横尾義貫 : 大スパントラス構造物の 耐罻性に関する研究一上下地祳動を受ける平行弦トラスばり の耐带性について一, 日本建築学会構造系論文埌告集, 第 360 号, pp. $64 \sim 74,1986.2$

9 ）和田 章, 向 秀元：一方向スパン䙡層円筒トラス構造物の 地縟応答解析， 日本建築学会構造系論文報告集，第413号， pp. 87〜96, 1990. 7

10）大屋竹之：鉄骨立体骨組構造の耐震性に関する研究，東京工 業大学博士学位論文, 1969.12

11）日建設計・大阪本社：大阪城国際文化スポーツホールの構造 設計，日本建築総合試験所G B R C, Vol. 8，pp. 10 20, 1983

12) Zhang, Y., Lan, T. : Analysis of Space Frame under Vertical Earthquake Loads, IABSE 12 th Congress Final Report, pp. 169 176, 1984

13）日本建築学会：建築物荷重指針・同解説。 1993

14）加藤史郎, 向山洋一，植木隆司：高ライズの単層ラチスドー 么の地震応答性状，日本建築学会構造系論文報告集，第442 号, pp. $101 \sim 109.1992 .12$

（1994 年 5 月 10 日原稿受理，1994 年 10 月 4 日採用决定） 